\title{
Anatomy of the CNS opioid systems
}

\author{
Henry Khachaturian, Michael E. Lewis, Martin K.-H. Schäfer and Stanley J. Watson
}

The amino actd sequences of the three endogenous opioid peptide precursors are known, and the anatomical distribution of the opioid peptides has been studied extensively This report summarizes these anatomical studies and looks at the problems that result from the biochemical relatedness of the precursors We also discuss the relationship of opioid systems to opioid receptors, and the use of anatomical studies to derive new hypotheses of opioid function and provide dynamic measures of opıoid neural activity, especially via spectfic $m R N A$ quantitation.

The anatomical distribution of endogenous opioid peptides in the brain has been studied extensively, and has often preceded the complete structural characterization of the precursors from which these peptides are derived In fact, immunocytochemical studies in all three cases established the cellular co-localization of opioid and related peptides either prior to or simultaneously with the biochemical and molecular biological establishment of their co-synthesis from a single precursor molecule The structures of all three opioid precursors, as determıned from these approaches, are shown in Fig 1. Due to necessary limitations in the space avallable for describing three major, widely distr1buted neuronal systems, we have focused on the most salient features of these systems and have necessanly limited the citations of a wide body of important literature on these peptides. We have also restricted our anatomical descriptions (except where necessary) to observations made in the rat CNS and pituitary Suffice it to say that significant species differences have been noted in the distnbution of CNS opioids For further detall, and a more complete list of references, the reader is referred to recent reviews

\section{Pro-opiomelanocortin}

Peptides derived from pro-opiomelanocortın (POMC) include the opioid $\beta$-endorphin, and the nonopioid hormones ACTH and $\alpha$-MSH (Fig 1) The POMC precursor is synthesized in both the pituitary gland as well as the brain (Figs 2 and 3 )

The pituitary gland is a major site of POMC biosynthesis Although the existence of the pituitary peptides $\mathrm{ACTH}$ and $\alpha-\mathrm{MSH}$ was already well established, the isolation and charactenzation of $\beta$-endorphın as an opiateactive peptide in 1976 by several laboratones $^{3}$ prompted extensive immunohistochemical studies begin-

\section{PROENKEPHALIN}

$=$ TYR $-G L Y-G L Y-P H E-M E T$ ning with the localization of $\beta$-endorphin, $\alpha$-endorphin and $\beta$-lipotropin (a POMC fragment containıng $\beta$-endorphin) immunoreactivities in the anterior lobe corticotrophs and intermediate lobe melanotrophs ${ }^{4}$ Electron-

microscopic immunocytochemistry further demonstrated the existence of $\beta$-lipotropin and ACTH in the same pituitary granules 5 , thus raising the possibility of a biosynthetic link between these peptides Further biochemical studies ${ }^{6}$ finally elucidated the protein structure of the POMC precursor which is processed to yield ACTH and $\beta$-endorphin in the anterior lobe, but $\alpha$-MSH and $\beta$-endorphin in the intermediate lobe The full structure of the POMC precursor was later deduced from the sequence of cDNA clones of POMC mRNA (Ref 1)
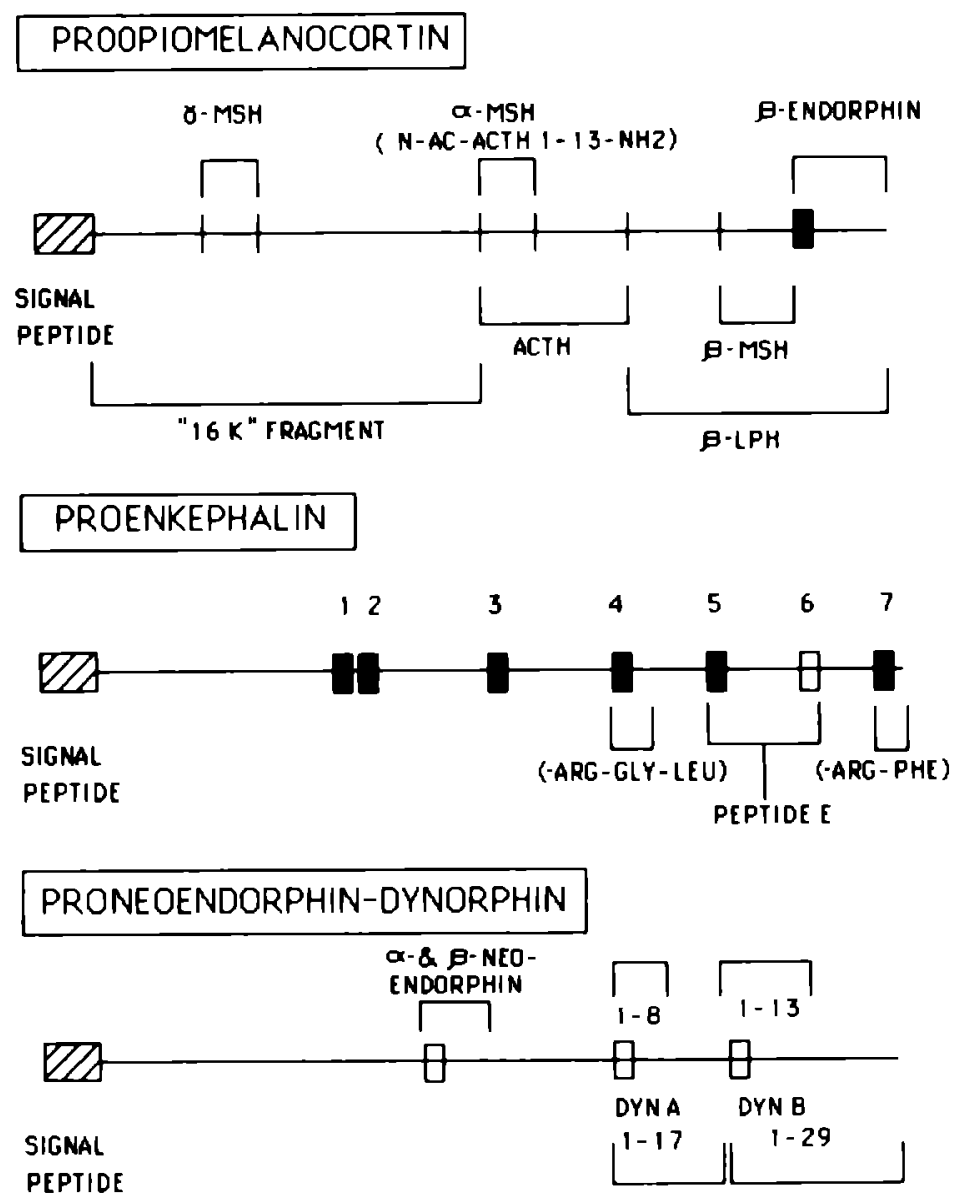

$=T Y R-G L Y-G L Y-P H E-L E U$

Fig. 1. Schemattc representation of the structure of the three optoid pepnde precursors Note that the opiate-active core sequence Tyr-Gly-Gly-Phe-Met (IMet/enkephalin) appears in both prooptomelanocortin and proenkephalin, while the opiate-active sequence Tyr-Gly-Gly-Phe-Leu ((LeuJenkephalin) is common to both proenkephalin and pro-neoendorphin-dynorphin (C) 1985, Elsevier heience Publsshers B V', Amsterdam $0167-3157 / 85 / \$ 0200$ For technical reasons we are unable to reproduce figure 2 of this article in colour in this edition - see the March issue centrefold of Trends in NeuroSctences for full colour illustration 


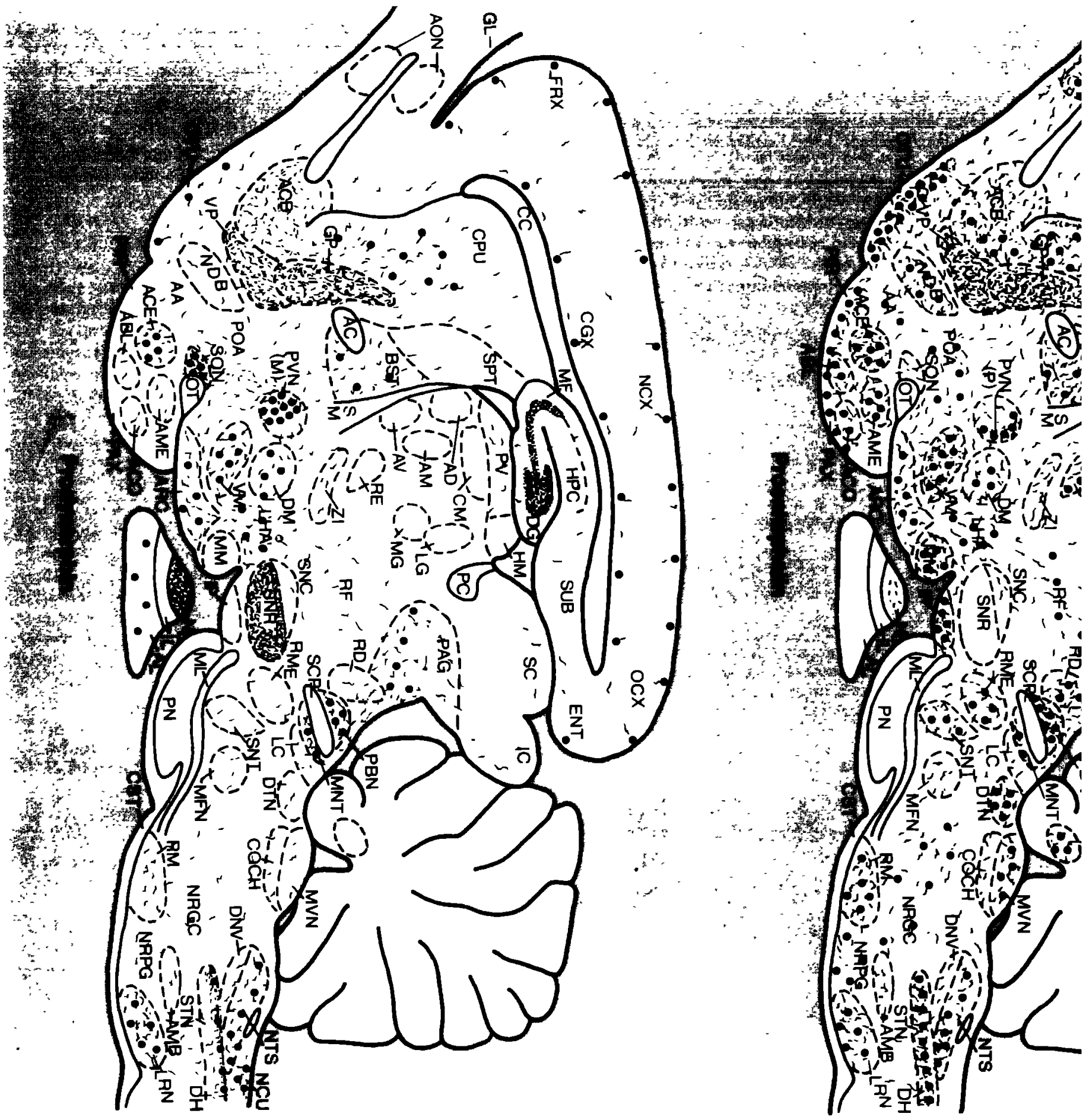

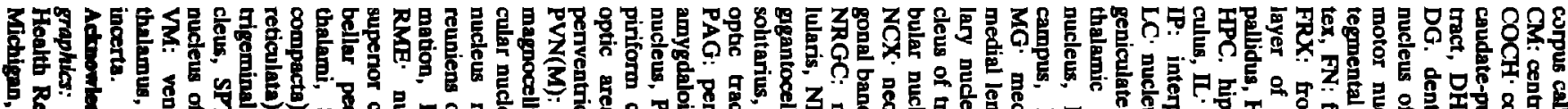
争 它

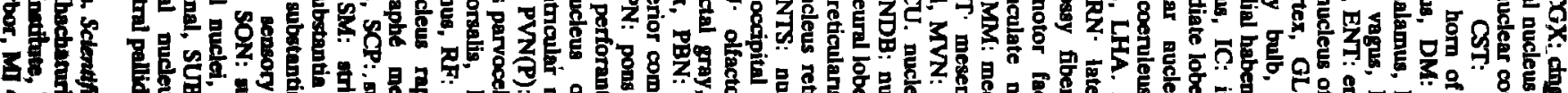
35 Cr.

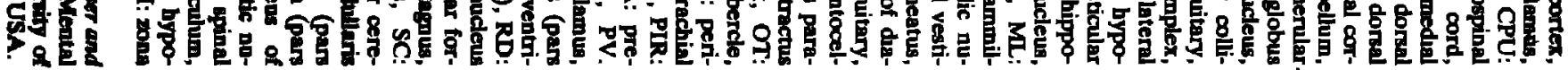




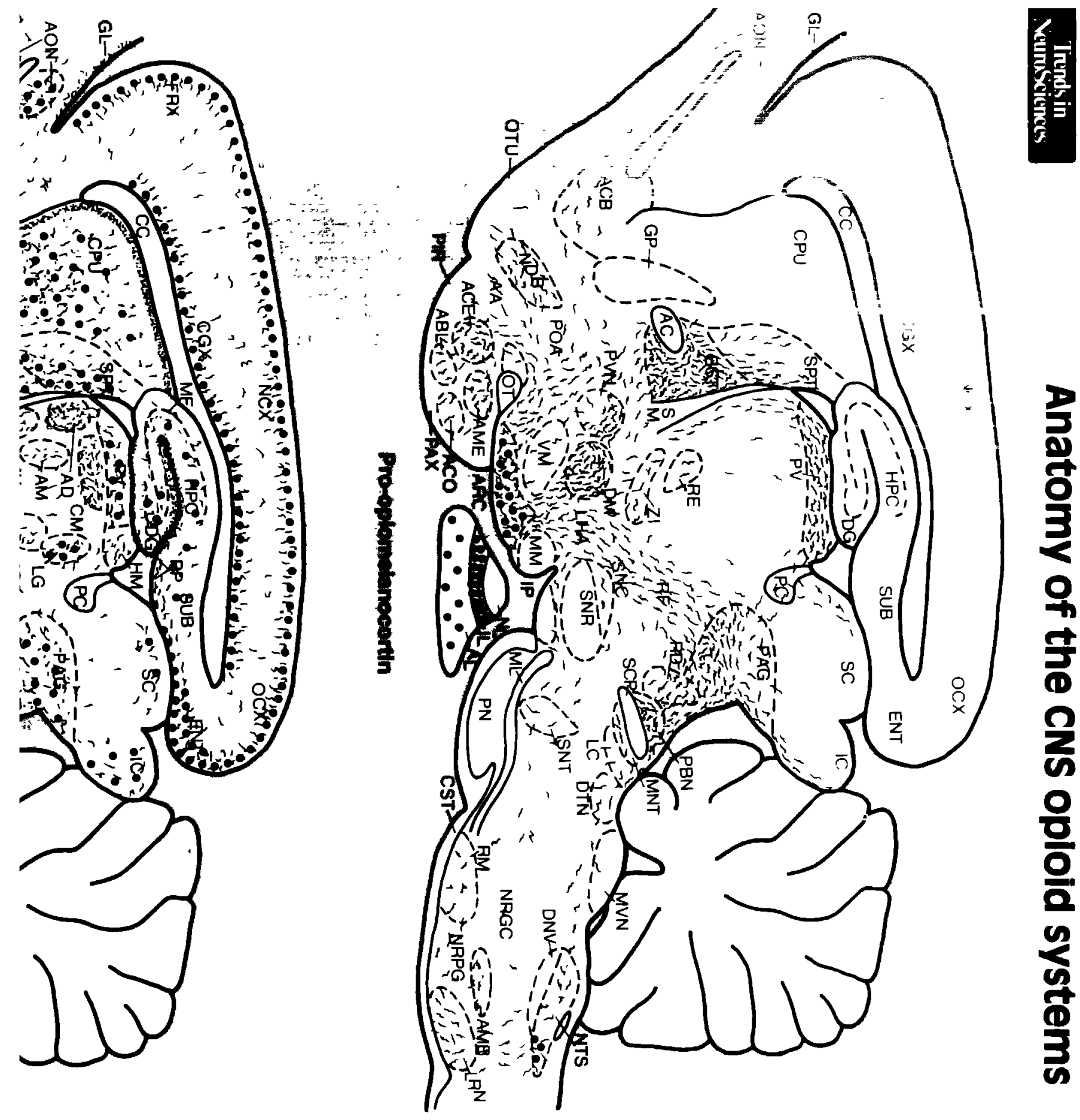

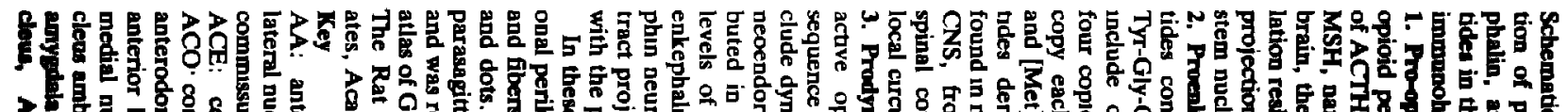

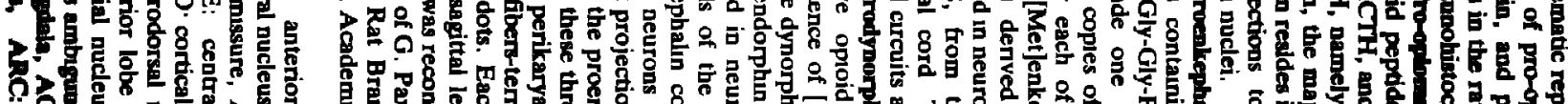
万人民

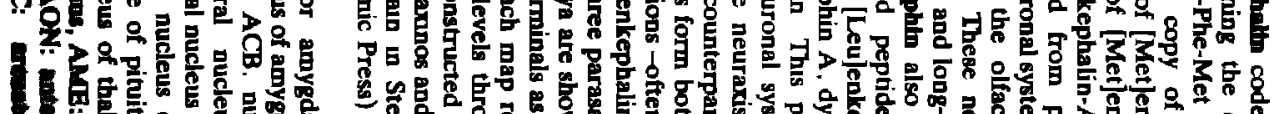
8

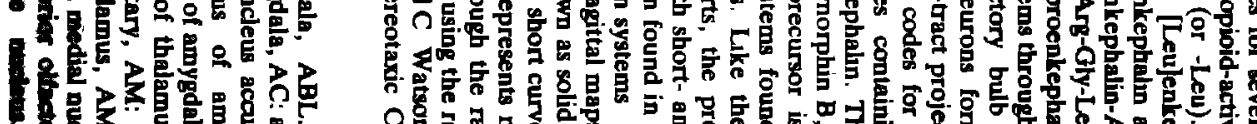

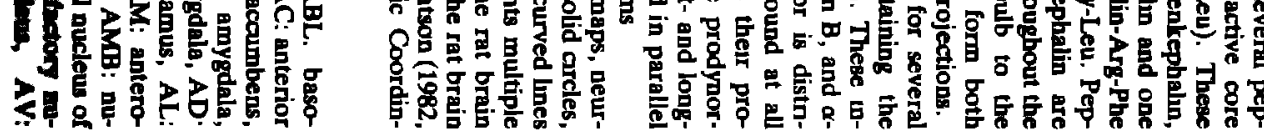
: r bin (X)

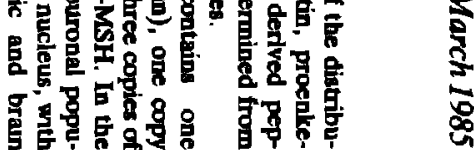


In the brain, there are two distinct cell groups which contain POMCdenved peptides. The first is located in the arcuate nucleus and with some cells scattered along the penarcuate medial-basal hypothalamus (Fig 3A) The second is found in the caudal nucleus tractus solitarius (Fig 3B) Bloom et al. ${ }^{7}$ and Watson et al ${ }^{8}$ demonstrated ACTH, $\beta$-lipotropin, and $\beta$-endorphun Immunoreactivities to be localized in neurons of the arcuate nucleus, and showed that these perikarya are distınct from those containing the enkephalins Later, $\beta$ endorphin, $\beta$-lipotropin, and ACTH immunoreactivities were all found to be co-localized in the same arcuate neurons ${ }^{9}$, an observation which was confirmed by other investugators (Ref 2) Simılar co-localızation studies were also carried out using $\alpha$-MSH antısera ${ }^{10}$, raising the possibility of a brain POMC processing mechanısm similar to that shown to occur in the intermediate lobe Watson and $\mathrm{Aksl}^{10}$ further demonstrated a second, widespread, extra-arcuate hypothalamic a-MSH-ımmunoreactive cell group whıch did not exhıbit immunoreactıvity for any other POMC peptides Although the exact chemical nature of the $\alpha$-MSH Immunoreactive product of these neurons is still unknown, these neurones apparently project heavily to the striatum, hippocampus, and cerebral cortex Later, at the annual meeting of the Society for Neuroscience in 1981, Schwartzberg and Nakane ${ }^{11}$ demonstrated another group of neurons which contained $\beta$ endorphin, $\mathrm{ACTH}$ and $16 \mathrm{~K}(\mathrm{~N}$-terminal fragment of POMC) immunoreactive material ( $F_{1} g$ 3B) This group of small neurons resides withın the commissural nucleus and caudal nucleus tractus solitarıus, and exhibits projections that extend laterally and may innervate the lateral reticular nucleus

The POMC neurons located in the arcuate nucleus have extensive projections throughout the brain (Figs 2 and 4), with the possible exception of the striatum, hippocampus, and cerebra cortex $^{12}$ Rostrally projecting fibers course through periventricular diencephalic and telencephalıc areas, innervating many hypothalamic and limbic structures, including preoptic area, septum, and the bed nucleus of stria termunalıs. Lateral projectıons of the arcuate POMC neurons extend through the medial-basal hypothalamus ventrally and enter the amygda-

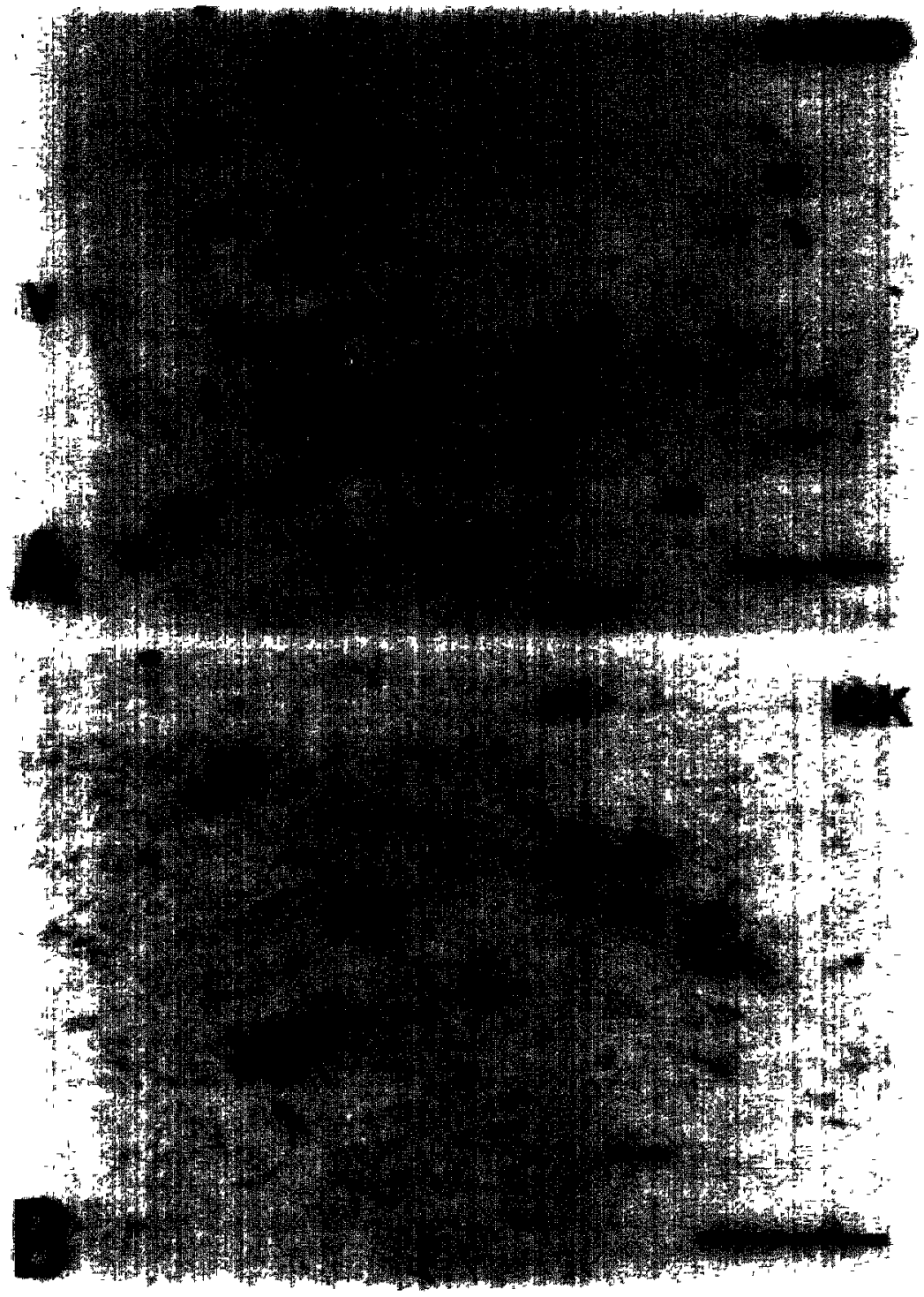

Fig. 3. (A) show's B-endorphin (B-END) immunoreactive neurom an the arcuat illuteus of $x_{t h}$ hypothalamus ( $V$ therd ventricle, calibration bar $=100 \mu \mathrm{m}$ ) In $(\mathbf{B}) 16 \mathrm{~K}$ immunoreac at e perkary a ar. seen in the nucleus tractus solstarius, pars commussurals of a one-dat-old postnatal rat " whbratuon his $50(u)$

loid region of the temporal cortex Dorso-caudally projecting fibers course through the dorsal diencephalon to enter the mesencephalon and brainstem, innervating many areas associated with nociceptive and other sensory integration These areas include the penventricular thalamus (Fig 4A) and penaqueductal gray (Fig 4B) Other caudal projections enter the brainstem ventrally to innervate numerous areas of the reticular formation, such as nucleus reticularıs gigantocellularis, retıculans lateralıs, and raphé magnus. Further brainstem sites contauning POMC immunoreactivity include the nucles parabrachialis and ambiguus, nucleus tractus solitanus, and dorsal motor nucleus of vagus, areas that are involved in respiratory and cardiovascular regulation

\section{Proenkephalin}

Unlike the POMC precursor which contains only one opioid peptıde $(\beta$ endorphın), several opiate-actıve peptıdes are derived from proenkephalin (Fig. 1) These are [Leu]enkephalin. [Met]enkephalin, [Met]enkephalınArg-Phe, [Met]enkephalin-Arg-GlyLeu, and potentially several larger oploids (e.g BAM-22P, peptides E and F) The proenkephalın precursor 
Is synthesized in many neuronal systems throughout the CNS, from the cerebral cortex down to the spinal cord (Figs 2 and 5A).

[Leu]- and [Met]-enkephalın were first isolated from the brain by Hughes et al. ${ }^{13}$ in 1975 and were shown at that time to be oplate active. The first Immunocytochemical studies by Elde et al $^{\mathbf{1 4}}$ and others ${ }^{2}$ demonstrated a very simular distribution pattern for both [Leu]- and [Met]-enkephalin in brain neurons, which was apparently different from that seen for $\beta$-endorphın and related peptides ${ }^{7,9}$ These prelıminary studies were followed by many immunohıstochemical studies descnbing enkephalinergic neuronal systems, some forming local circuits, and others with long-tract projections $^{15-19}$ It is of course now known that [Met]- and [Leu]-enkephalın along with certain other $C$-terminally extended enkephalin peptides are all denved from a single precursor, proenkephalin, the structure of which was deduced from molecular cloning and sequencing of cDNA from proenkephalın mRNA (Ref. 1)

To date, most immunocytochemical studies of CNS enkephalın-containıng neuronal systems are in good agreement regarding the widespread nature of these peptides More recently, the use of relatively higher doses of the neurotoxın colchicine, which inhıbits microtubular axonal transport of nerve cell products, has enabled investigators to detect many more enkephalın perikarya Thus, in addition to the many brainstem, mesencephalic and diencephalic enkephalinergic neuronal systems described previously, we and other investigators have been able to detect extensive hippocampal, amygdaloid, cortical and other telencephalic neuronal circuits which exhıbit enkephalin ımmunoreactivity ${ }^{18.19}$ In these and numerous other studies of proenkephalın distnbution in CNS, it was consistently noted that enkephalın-containing neurons often existed in many brain areas alongsıde dynorphın-containıng neurons (Fig 5) Whether or not some CNS neuronal penkarya co-store these precursors is currently not known.

Neurons containıng proentesphalin peptides are found at virtually all levels of the neuraxis (Fig 2). Immunoreactive perikarya have been noted in most regions of the telencephalon, including the cerebral cortex, olfactory tubercle, amygdala, hıppocampus, stnatum, septum, bed nu- cleus of stna terminalis and preoptic area. In diencephalon, penkarya are seen in most hypothalamic nuclei (Fig. 5), and in the periventncular and lateral geniculate nucleus of thalamus. In the midbrain, enkephalinergic cells are localized in the colliculi, periaqueductal gray, and interpeduncular nucleus In the pons and medulla, perikarya are seen in the parabrachial, dorsal tegmental, vestibular and raphé nuclei, nuclei reticulans gigantocellularis and paragigantocellularis, nucleus tractus solitanus, lateral retıcular nucleus, spinal trigeminal nucleus and spinal cord dorsal gray In addition to these areas which contain both enke- phalın perikarya and fibers, numerous other brain regions exhıbit varying densities of fiber and terminal-like 1mmunoreactivity (Figs 2 and 6). From the foregoing, it should be apparent that the enkephalıns have the potential to influence a wide vanety of CNS functions ${ }^{1,2}$

\section{Prodynorphin}

Prodynorphin (or pro-neoendorphın-dynorphın), lıke proenkephalın, contains several opiate-active peptıdes, including dynorphin $\mathrm{A}$, dynorphin B (nmorphin), and $\alpha$ - or $\beta$ neoendorphin (Fig. 1) This precursor is also synthesized throughout the

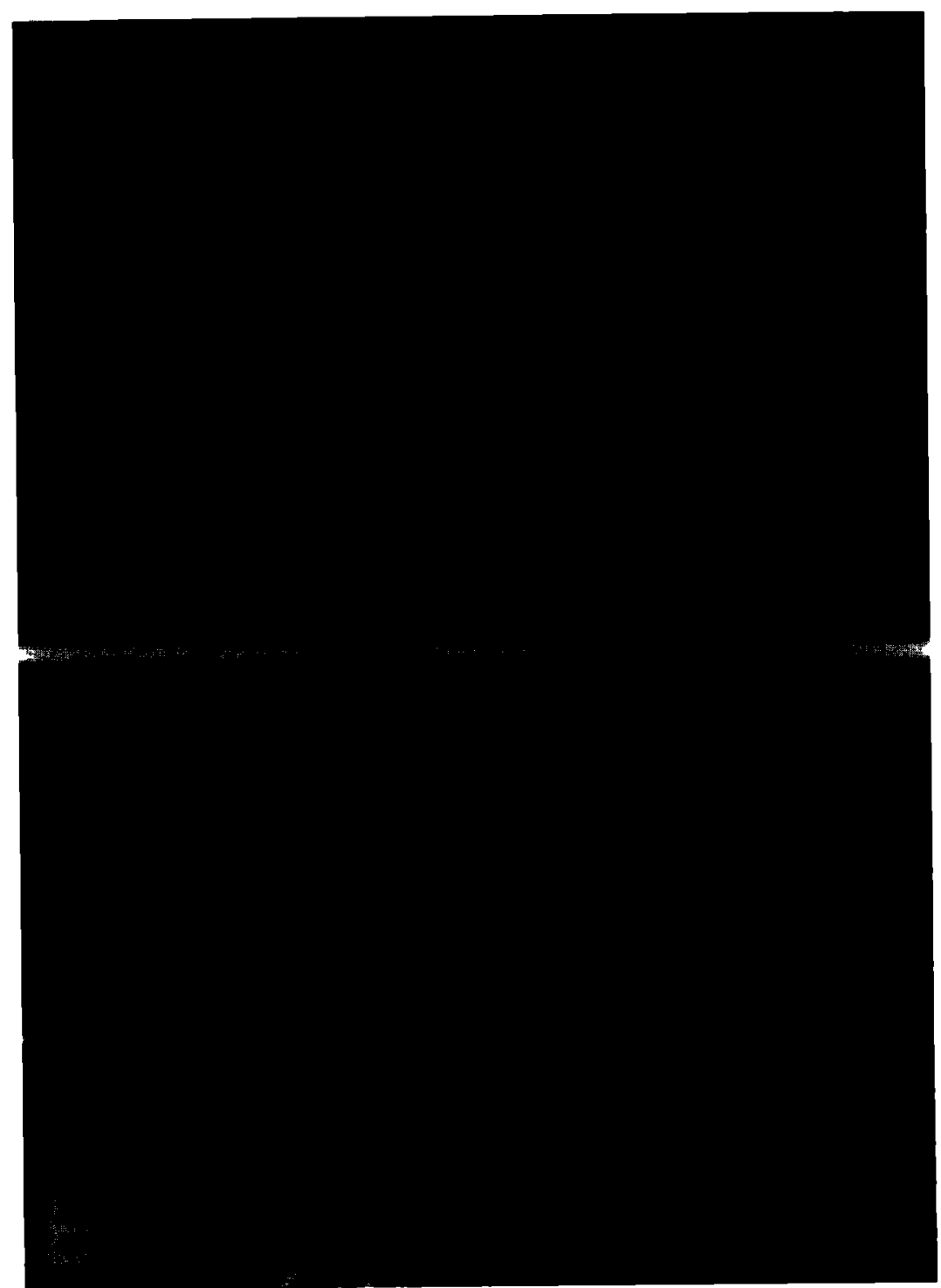

Flg. 4. $\beta-E n d o r p h i n ~(\beta-E N D)$ immunoreactive fibers in parasagittal sections through the periventricular nucleus of thalamus (A) and the periaqueductal gray of mesencephalon (B) Compare with Fig 2 POMC projections. Micrograph made using darkfield optics AQ cerebral aqueduct, $V$ lateral ventricle Calibration bar $=200 \mu \mathrm{m}$ 
CNS in a wide vanety of neuronal systems (Figs 2 and 5B).

In 1979, Goldstein et al ${ }^{20}$ extracted from pitutary a 13 amıno acıd peptıde which contained the [Leu]enkephalin sequence at its $N$-terminus. The full 17 amino acid structure of this peptide, now called dynorphin $\mathbf{A}$, was later elucidated. The second [Leu]enkephalin-containing fragment of the precursor to be isolated was $\alpha$-neoendorphin, which was extracted from the hypothalamus and fully sequenced $A$ third peptide, shown to be part of the $C$ terminus extension of dynorphin $A$, was also identified and termed dynorphın B or rimorphın ${ }^{1}$. Watson et al. ${ }^{21}$ demonstrated dynorphin A(1-13) immunoreactivity in the postenor lobe of pituitary, and in hypothalamic supraoptic and paraventricular nuclei, and further showed this peptide to be co-localized with arginine-vasopressın in some magnocellular perikarya ${ }^{22}$. Similar observations were also made using antısera raised against dynorphin $B$ and $\alpha$-neoendorphin, showing these peptides and dynorphin $A$ to be colocalized within the same neurons in several regions of the brain ${ }^{23,24}$ These results were in good agreement with the cloning and sequence analysis of prodynorphin cDNA demonstrating the co-synthesis of these peptides from a sıngle precursor ${ }^{1}$.

Further immunocytochemical studIes of dynorphin distribution in the CNS soon followed the intial observations, and, as was the case with the enkephalıns, the application of colchlcine enabled the detection of increasing numbers of smaller dynorphin penkarya throughout the brain and spinal cord ${ }^{19,24-26}$. Our observations are summarized in Fig 2. Immunoreactıve dynorphin perikarya are distnbuted in several cerebral cortıcal areas, striatum, amygdala, hippocampus, several hypothalamic nucle (Including the supraoptic and paraventricular), midbrain periaqueductal gray, and numerous brainstem areas, such as the parabrachial and spinal tngemınal nuclei, nucleus tractus solitarius, lateral reticular nucleus, and in the spinal cord dorsal horn. Additionally, fiber immunoreactivity is seen in many other areas of the brain as depicted in Figs 2 and 7 Mention should also be made of dynorphin immunoreactivity in some as yet unidentified cells of the pituitary antenor lobe (Fig. 7B). However, these cells are distinct from the corticotrophs which synthesize POMC When com-

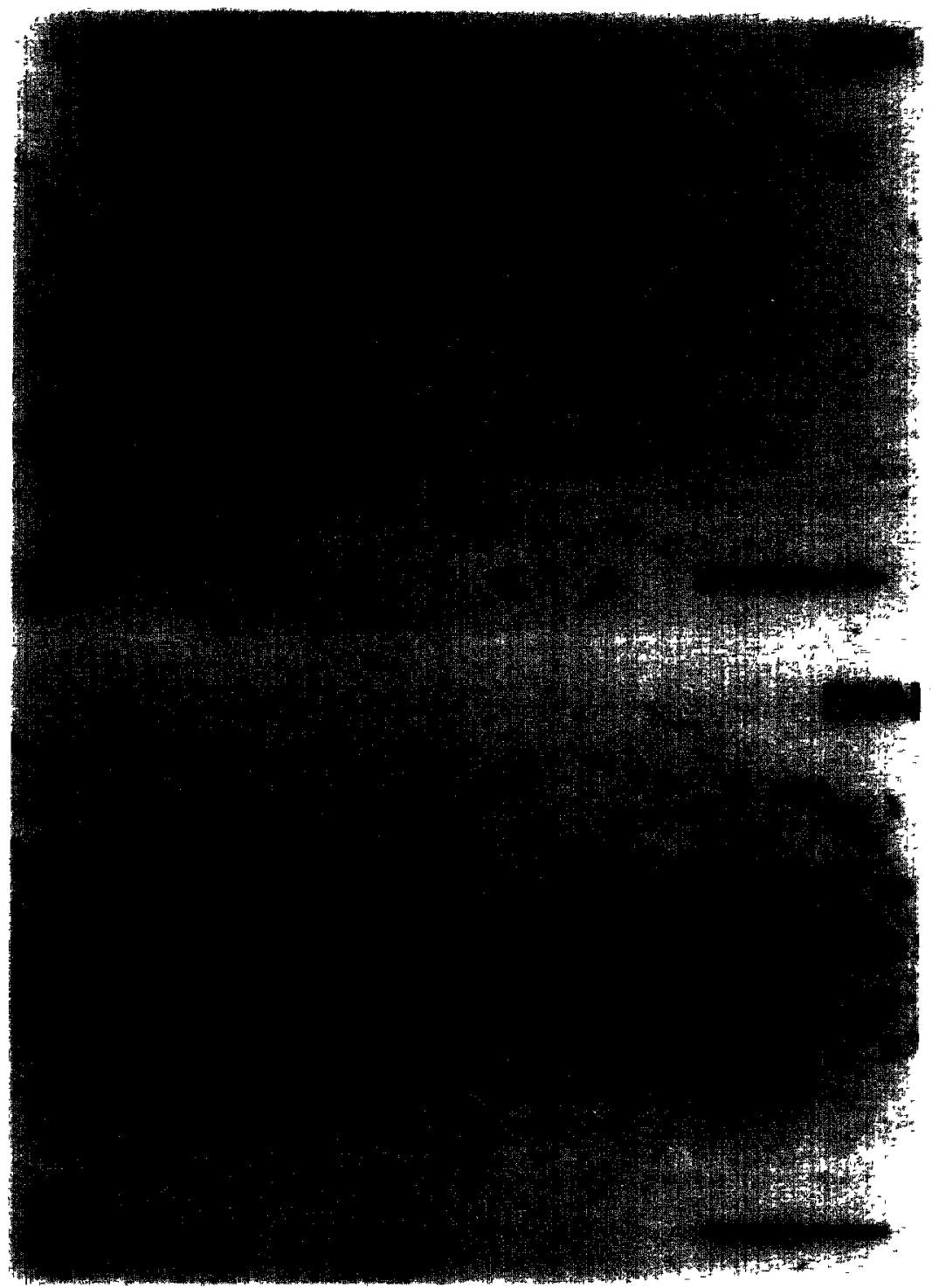

Fig. 5. Adjacent $4 \mathrm{um}$ sections through the hypothalamic paraventricular nucleus (lett is mediol, immunostaned for /Leulenkephalin (ENK)(A) and dynorphin B (DYN)(B) Stars indicate a common vessel Note that the majority of / LeuJenkephalin cells are concentrated in the parvocellular subdivision (dorsal and medal to the vessel), while most dynorphin $B$ cells is in the magnocellular part (lateral to the vessel) Caltbration bar $=100 \mathrm{um}$

panng the CNS distribution of the dynorphins and the enkephalins, it becomes obvious that these two systems are often anatomically contıguous (see Fig 5), and thus may participate (possibly via different receptors) in several related CNS functions

\section{Problems of sequence bomologies among the opioids}

Since the opıate-active core sequence of all opioid peptides consists of either [Met]enkephalin or [Leu]enkephalin ( $F_{1 g}$ - 1), there has been considerable difficulty and confusion in the immunocytochemical as well as brochemical separation of these peptides For example, the earlier observations of [Met]enkephalın-like $1 \mathrm{~m}$ munoreactivity in the antenor lobe corticotrophs and intermediate lobe cells were obviously due to significant antibody cross-reactivity and/or enzymatic degradation that resulted in the detection of the $N$-terminal [Met]enkephalin sequence of $\beta$-endorphin In these cells In the case of [Leu]enkephalin, however, we are faced with a considerably more difficult task. The amıno acid sequence of this pentapeptide is found in two opioid precursors 
proenkephalın, which contains one copy, and prodynorphin, which contains three copies as part of the $N$ termınal sequence of $\alpha$-neoendorphın, dynorphın A and dynorphin B As noted before, proenkephalın and prodynorphın neurons are often found in the same regions of the brain (Fig. 5), complicating the separation of the two precursor systems One of the most extensively investigated systems is the hypothalamic magnocellular paraventricular and supraoptic nuclei which synthesize the neuropeptides oxytocin and vasopressin These cells project to the neural lobe of the pituitary Initially, [Leu]enkephalın was extracted from the neurointermediate lobe of rat pituitary and was shown to be localized in the magnocellular nuclei ${ }^{27}$. Rossier et al. ${ }^{27}$ first suggested this peptide to be involved in the regulation of vasopressin and oxytocin. Martin and Voigt ${ }^{28}$ demonstrated the coexistence of [Met]enkephalın with oxytocin and [Leu]enkephalin with vasopressin in neurosecretory termınals of the rat neurohypophysis. However, the [Leu]enkephalın antiserum used was blockable by dynorphin $\mathbf{A}$ Subsequently, Watson et al. ${ }^{22,29}$, using highly punfied antisera, showed that prodynorphin is associated with vasopressin in magnocellular neurons and that [Leu]enkephalın and other proenkephalın peptides are found in the parvocellular part of the paraventncular nucleus (Fig 5). However, signıficant species differences appear to exist in the processing of prodynorphin in the magnocellular nucle! For example, in the cat, substantial amounts of [Leu] enkephalın can be seen in the supraoptic nucleus ${ }^{30}$ We have also made similar observations in the rhesus monkey magnocellular system Recently, indirect evidence has also been presented for the processing of prodynorphin of stnatal origin into [Leu]enkephalın in the rat substantia nigra $^{31}$ However, we have previously shown in the rat that [Leu]enkephalin in substantia nigra is concentrated primanly in the pars compacta while dynorphin A is found mainly in the pars reticulata $^{29}$ In fact, through the use of antisera directed against various proenkephalın and prodynorphin peptıdes, we have seen the peptides derived from each precursor co-localized withın distınct enkephalın-containing and dynorphin-containıng neurons ${ }^{23,29,32}$ Of course, these observations do not necessarily exclude processing of some prodynorphin to
[Leu]enkephalin in termınal fields. Nevertheless, because of the close anatomical proxımity of the enkephalins and dynorphins, biochemical data should also be regarded with caution since it is difficult to obtain tissue samples which contain one but not the other precursor.

\section{Opioid peptide-receptor relationships}

Given the anatomical complexity and relatedness of the multiple opıoid systems, it is worth asking how the 'messages' of these systems are differentiated at the receptor level. Although there is abundant pharmacological and biochemical evidence for
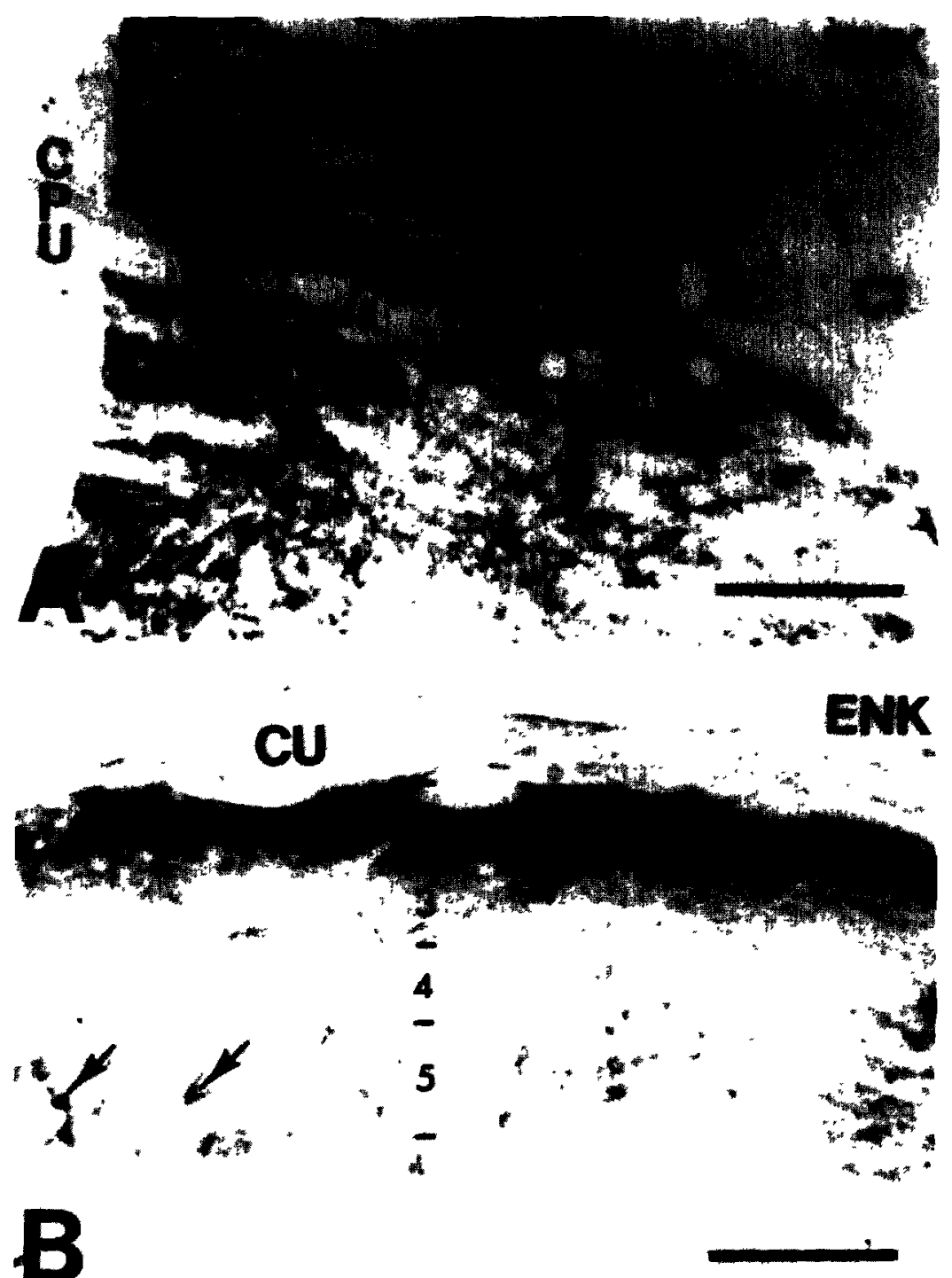

Fig. 6. (A) and (B) are parasagittal sections showing the distribution of /Leu/enkephalin (ENK) immunoreactivity in the globus palludus $(A)$ and the dorsal horn of the spinal cord $(B)$ In (B) (cervical cord), note the dense immunoreactuvty in laminae 1 and 2. and scattered immunoreactive perikaryo (arrows) in lamma 5 Compare with Fig 2 proenkephaltn projectons CI internal capsule, CPU caudate-putamen, $C U$ fasciculus cuneatus Calibration bar $=200 \mu \mathrm{m}$

multiple subtypes of opioid receptors $^{33}$, the relationship of these receptors to the multiple opioid systems is not well understood However, there is some rationale for makıng predictions. In vitro, the enkephalins bind preferentially to $\delta$-opıoid receptors, while dynorphin-related peptides bind preferentially to $\boldsymbol{k}$-opıoid receptors, and $\beta$-endorphin binds to $\mu$ - and $\delta$-, but not $\mathrm{k}-$, oploid receptors ${ }^{33}$. Do these in-vitro associations predict anatomical relationships? To begin to explore this question, receptor autoradiographic and immunocytochemical studies were carned out on adjacent sections of formaldehyde-perfused rat and rhesus 
monkey brains ${ }^{34-36}$ Apparent $\mu$ - and $\kappa$-receptors are extensively co-locallzed in rat brain ${ }^{37}$, and are distributed simılarly to enkephalin immunoreactivity in many (but not all) CNS areas, e.g some cerebral cortical areas, habenula, interpeduncular nuclear complex, parabrachial nuclei, nucleus tractus solitarius, spinal tngemunal nucleus, and dorsal horn of the spinal cord Such findings indicate that the ligand-receptor anatomical associations predicted by in-vitro studies (e g enkephalın- $\delta$ ) appear incorrect Instead, since it is now known that some extended proenkephalın peptides have substantial $k$ and $\mu$ properties ${ }^{38}$, while dynorphin $A$ loses $K$ selectivity upon $C$-terminal cleavage ${ }^{38,39}$, the apparent availability of multıple opıoid receptors to each opıoid system may sıgnify that differential processing of the opıoid precursor is a biological strategy for yielding peptide products which act at the different receptors

\section{Derivation of hypotheses of opioid function from anatomy}

Whenever neuroanatomical studies are carried out, there is always the hope that some aspect of neural function will be illumunated. The study of the anatomical distribution of opıoid peptides and receptors has not been disappointing in this regard; for example, opıord neurons and receptors are clearly part of the neural apparatus involved in nociception and analgesia Given the classical pharmacology of opiates, this association is not surpnsing. However, the study of opıoid anatomy has given rise to less obvious possibılities. For example, the study of opioid receptor distribution has generated hypotheses concerning the role of opioids in multimodal sensory processing ${ }^{40,41}$ Based upon a sensory cortıcolimbic gradient of $\left[{ }^{3} \mathrm{H}\right]-$ naloxone binding sites in primate cerebral cortex, a possible role of opioids in selective attention was proposed $^{42}$ and supported by electrophysiological studies ${ }^{43}$ Immunocytochemical studies of opıoid peptide systems have also been useful not only in providing an anatomical 'ratıonale' for the actions of opioids on autonomic, neuroendocnne, and behavioral functions ${ }^{1,2,12}$, but also for predicting previously unconsidered physiological roles of these peptides For example, our observation of enkephalin perkarya in the motor and mesencephalıc nucles of the trigeminal may indicate a role for this opioid in the control of mastication ${ }^{17}$ Likewise, the presence of enkephalın penkarya in the oculomotor and prepositus hypoglossal nucleı suggests a possible role in the regulation of eye movements ${ }^{17}$ These examples show how anatomical studies can be useful in the generation of new hypotheses of opioid function in the CNS

\section{Toward a dynamic opioid anatomy}

The anatomical localization of opioid peptides has revealed exceedingly complex multiple systems. We are now faced with the task of unravel- ing the mynad of cell groups and projection systems in order to be able to derive further clues as to their functional significance Some of these projections have been determined with the use of combined immunocytochemical and tract-tracing techniques Numerous other projections are yet to be elucidated. For example, in the case of POMC, it has been assumed that all brain projections emanate from a single neuronal population residing in the hypothalamic arcuate nucleus However, the discovery of additional POMC neurons in

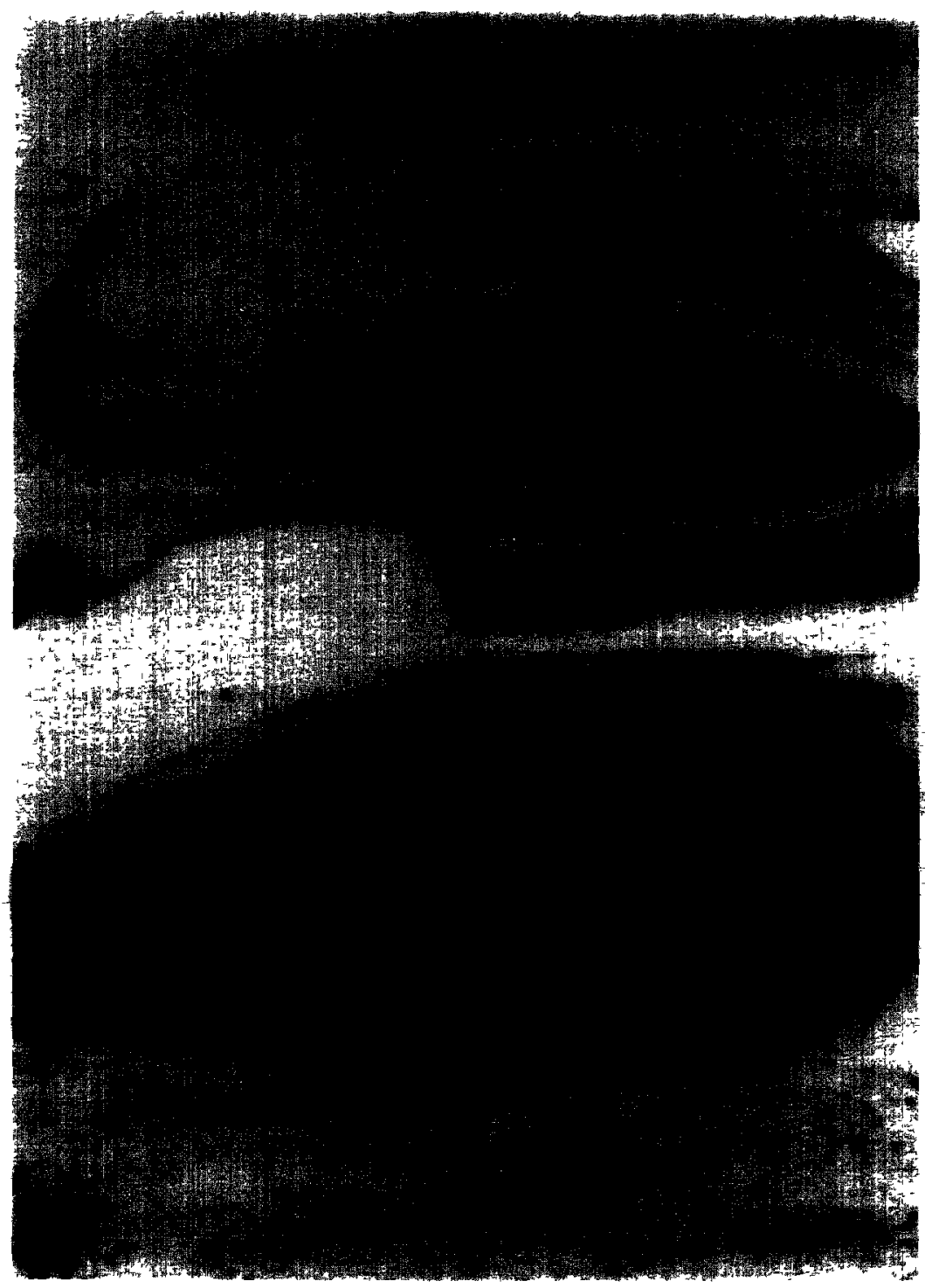

Fig. 7. Dynorphin A (DYN) immunoreactivity us shown in two parasagital level through the hippocampal formation $(A)$ and the pituitary gland (B) In (A) the dentate gyrus mossy fiber projections into areas $C A 2$ and $C A 3$ is $D Y N$-posinve (caltbration bar $=400 \mu \mathrm{m}$ ) $\mathrm{In}$ (B) the neural lobe contatss DYN immunoreactivity Note also several immunoreactive cells (arrows) in the antenor lobe (caltbration bar $=200 \mathrm{um}$ ) Compare with Ftg 2 prodynorphin projections AI anterlor lobe $C A I, 2,3$ cornu ammons fields 1,2 , and $3 I L$ intermediate lobe $N L$ neural lobe $S G$ stratum granulosum $S M$ stratum moleculare $S R$ stratum radiatum 
the nucleus tractus solitarius, and the fact that this nucleus (but not necessarily POMC neurons) projects to many POMC-rich brainstem and forebrain areas, makes it imperative to employ such combined immunocytochemical and tract-tracing techniques to begin to sort out the differential projections of these two POMC-containing neuronal groups. From this example, it should be apparent that a considerably more difficult and extensive task awaits us in the case of the proenkephalin and prodynorphin systems. Given this complexity, it would also be useful to be able to study the dynamucs of these systems in an anatomical context In-situ cDNA-mRNA hybridization histochemistry has already proven useful for the localization of POMC-synthesizing cells in pituitary and brain ${ }^{44}$, and recent studies have shown that this procedure can be used to detect the effects of physiological treatments on POMC mRNA levels ${ }^{45}$, which appear to provide an index of cellular biosynthetic activity. Thus, two major future directions of opiond anatomical studies will be to conduct detalled regional immunocytochemical analyses of opioid neuronal projections in combınation with tract-tracing methods, as well as in-situ hybndization of opioid mRNA, to begin to probe the functional significance of the multıple systems described in this review

\section{Acknowledgements}

This work was supported by NIDA Grant DA02265, NIDA Center Grant DA00154, NIMH Grant MH36168, NIMH Training Grant T32-MH15794 (M E L ) and the Theophlle Raphael Fund. We wish to thank Drs Elizabeth Eipper and Richard Mains for providing the $16 \mathrm{~K}$ fragment antiserum, and Adele Henry for manuscript preparation.

\section{Selected references}

1 Akıl, H, Watson, S J, Young, E, Lewis, $M$ E , Khachatunan, $H$ and Walker, $J \mathbf{M}$ (1984) Annu Rev Neurosct 7, 223-255

2 Watson, S J , Akıl, H , Khachatunan, H Young, E and Lewis, M. E (1984) in Optoids Past, Present and Future (Collier, H O J , Hughes, J, Rance, $M J$ and Tyers, M B , eds), pp 145-178, Taylor and Francis, Ltd, London

$3 \mathrm{Ll}, \mathrm{C} \mathrm{H}$ (1981) in Hormonal Proteins and Peptides (Li, C H , ed ), pp 2-30, Academic
Press, New York

4 Bloom, F E, Battenberg, E, Rossier, J , Ling, $N$, Leppaleuoto, J , Vargo, $T M$ and Gullemn, R (1977) Lıfe Scl 20, 43-48

5 Pellener, G , LeClerc, R , LaBne, F , Cote. J., Chretien, $M$ and Lis, M (1977) Endo. crinology 100, 770-776

6 Mains, R E , Eipper, B A. Glembotsk, C C and Dores, R M (1983) Trends NeuroScl 6, 229-235

7 Bloom, F E, Battenberg, E, Rossier, J , Ling, $N$ and Guillemin, R. (1978) Proc Natl Acad Sct USA 75, 1591-1595

8 Watson, S J, Richards, C W and Barchas, J D (1978) Sclence 200, 1180-1182

9 Watson, S J , Akıl, H., Richard, C. W. and Barchas, J D (1978) Nature (London) 275. 226-228

10 Watson, S. J and Akıl, H. (1980) Brain Res 182, 217-223

11 Schwartzberg, D G and Nakane, P K (1983) Brain Res 276, 351-356

12 Khachatunan, H, Lews, M E, Tsou, K and Watson, S $\mathrm{J}$ in Handbook of Chemical Neuroanatomy, Vol 4 (Hokfelt, $\mathrm{T}$ and Björklund, A, eds), Elsevier Biomedical Press, Amsterdam (1n press)

13 Hughes, J , Smith, T. W, Kosterlıtz, H W, Fothergill, L. A , Morgan, B A and Morns, H R (1975) Nature (London) 258, 577-579

14 Elde, $R$, Hokfelt, $T$, Johansson, $O$ and Terentus, L (1976) Neuroscience 1, 349-351

15 Hokfelt, T, Elde, $\mathbf{R}$, Johansson, $O$, Terenius, L and Stein, L (1977) Neuroset Letr 5, 25-31

16 Sar, N, Stumpf, W E, Miller, R J Chang, $\mathrm{K}-\mathrm{J}$ and Cuatrecasas, $\mathrm{P}$ (1978) $J$ Comp Neurol 182, 17-37

17 Khachatunan, H., Lewis, M E and Watson, S J (1983) J Comp Neurol 220, 310 320

18 Khachatunan, H, Lew1s, M E, Hollt, V and Watson, S J (1983) J Neurosci 3,844 855

19 MeGinty, J F, van der Kooy, D and Bloom, F E (1984) $J$ Neuroscl 4, 1104 1117

20 Goldsteın, A , Tachıbana, S , Lowney, L I., Hunkapillar, M and Hood, L (1979) Proc Nall Acad Sa USA 76, 6666-6670

21 Watson, S J, Akıl, H, Ghazarossian, V E and Goldstein, A (1981) Proc Natl Acad Sct USA 78, 1260-1263

22 Watson, S J , Akıl, H, Fischl, W, Gold steın, A., Zimmerman, E A, Nılaver, G and van Wimersma Gnedanus, T B (1982) Science 216, 85-87

23 Watson, S J , Khachatunan, H , Taylor, L , Fischl, W, Goldsteın, $A$ and Akıl, $H$ (1983) Proc Natl Acad Sci USA 80, 891894

24 Weber, E and Barchas, J D (1983) Proc Natl Acad Sct USA 80, 1125-1129

25 Khachatunan, H , Watson, S J , Lewis M E , Coy, D , Goldsteın, A and Akıl, H (1982) Pephdes 3, 941-954
26 Vincent, S R, Hokfelt, T, Christensson, I and Terenius, L (1982) Neurasc Lett 35 185-190

27 Rossier, J , Battenberg, E, Pittman, O , Bayon, A , Koda, L , Miller, R , Gullemin, $R$ and Bloom, F E (1979) Nature (London) 277, 653-655

28 Martin, $R$ and Voigt, K H (1981) Nature (London) 289, 502-504

29 Watson, S J , Khachatunan, H , Akıl, H , Coy, D and Goldstein, A (1982) Sclence 218, 1134-1136

30 Micevych, P and Elde, R (1980) J Comp Neurol 190, 135-146

31 Zamir, N, Palkovits, M, Weber, E, Mezey, E and Brownstein, M J (1984) Nanre (London) 307, 643-645

32 Khachatunan, $H$, Lews $M E$ and Watson, S J (1983) Bran Res 279, 369-373

33 Robson, L E, Paterson, S J and Kosterlitz, H W (1983) in Handbook of Psychopharmacology (Iversen, L L, Iversen, S D and Snyder, S H, eds), pp 13-80, Plenum Press, New York

34 Lewis, M E, Khachaturian, $\mathbf{H}$ and Watson, S J (1982) Lıfe ScI 31, 1347-1350

35 Lewis, $M E$, Khachatunan, $H$ and Watson, S J (1983) Llfe Sci 33, 239-242

36 Lewis, M E, Khachatunan, $H$ and Watson, S J Pepthdes (in press)

37 Quinon, R, Bowen, W, Herkenham, M and Pert, C B (1982) Cell Mol Neurobiol 2, 333-345

38 Quinon, R and Weiss, A S (1983) Peptudes 4, 445-449

39 Corbett, A D, Paterson, S J , McKnıght, A T , Magnan, J and Kosterlitz, H (1982) Nature (London) 299, 79-81

40 Herkenham, M and Pert, C B (1980) Proc Natl Acad ScI USA 77, 4469-4473

41 Lewis, M E, Pert, A, Pert, C B and Herkenham, M (1983) J Comp Neurol 216, 339-358

42 Lewis, M E, Mishkin, M, Bragın, E Brown, $\mathbf{R}$ M, Pert, C B and Pert, A (1981) Sclence 211, 1166-1169

43 Amsten, A F T, Segal, D S, Neville, H J, Hillyard, S A, Janowsky, D S , Judd, L L and Bloom, F E (1983) Nature (London) 304, 725-727

44 Gee, C E, Chen, C-L C, Roberts, J L Thompson, R and Watson, S J (1983) Nature (London) 306, 374-376

45 Gee, C E and Roberts, J L (1983) DNA $2,157-163$

46 Paxinos, G and Watson, $C$ (1982) in The Rat Brain in Stereotaxic Coordinates, Academic Press

Henry Khachaturian, Michael E Lewis and Stanley $J$ Watson are at the Mental Health Research Institute, University of Michigan, Ann Arbor, MI 48109, USA Martin K-H Schafer is at the Sekton Elektronmikroskopie, Universtiat Ulm, FRG 